\title{
Pembentukan Akhlak melalui Suri Tauladan Rasullulah pada Anak Usia Sekolah Dasar
}

\author{
Siti Fatimah1, ${ }^{1}$ Sutrisno ${ }^{2}$
}

1,2Pendidikan Guru Madrasah Ibtidaiyah, Fakultas Ilmu Tarbiyah Dan Keguruan Universitas Islam Negeri Sunan Kalijaga Yogyakarta Jalan Marsda Adisucipto, Daerah Istimewa Yogyakarta, 55281

Email: 20214081016@student.uin-suka.ac.id, sutrisno@uin-suka.ac.id

\begin{tabular}{l}
\hline Article Info \\
\hline Article History \\
Received: 2021-11 \\
Revised: 2021-12-1 \\
Published: 2022-01 \\
\\
Keywords: \\
Establishment; \\
Morals; \\
Role Models; \\
Rasulullah; \\
Child.
\end{tabular}

\section{Abstract}

Morality is a trait embedded in the human soul, so that he will appear spontaneously whenever needed, without the need for prior thought or consideration. Be of noble character in the teachings of Islam which is praised by Allah and exalted in rank. Good moral education can be seen from how Rasulullah in behaving Rasulullah became an example that should be able to be exemplified both in speech and in the form of actions. Because the morals or actions of the Prophet are the same as what God commanded. Rasulullah is an example that Muslims must be able to follow. The personality of the Prophet Muhammad is the most appropriate example to be used as an example in shaping the personality can be seen from the way the Prophet educated his children. Therefore, through the example of the Prophet, he gave a high contribution to the formation of morals for children of primary school age. The purpose of this study is to find out how the formation of morals through the role model of the Prophet in primary school children. This research is against the background of the decline in morale of 5 th grade students of SD Negeri 01 Braja Luhur. This study uses a type of descriptive qualitative research with research subjects of one grade teacher and six 5th grade elementary school students. Data collection techniques were performed by interviews, observations, and documentation. Data analysis techniques using the Miles and Huberman model are data reduction, data presentation, and verification or conclusion. Test the validity of the data in this study using 2 triangulation models, namely source triangulation and engineering triangulation. The content of this research is about 1) The efforts of the Prophet to educate his children in his family 2) The implementation of the formation of morals through the role model of the Prophet in primary school children.

\begin{tabular}{l}
\hline Artikel Info \\
\hline Sejarah Artikel \\
Diterima: 2021-11-20 \\
Direvisi: 2021-12-15 \\
Dipublikasi: 2022-01-03
\end{tabular}

Kata kunci: Pembentukan; Akhlak;

Suri Tauladan;

Rasulullah;

Anak.

\begin{abstract}
Abstrak
Akhlak merupakan suatu tindakan yang sifatnya tertanam dalam diri manusia, dengan demikian keadaan tersebut akan muncul secara spontan apabila keadaan itu diperlukan, tanpa melalui sebuah pemikiran atau pertimbangan terlebih dahulu. Berakhlak mulia dalam ajaran Islam akan dipujikan oleh Allah dan ditinggikan derajatnya. Sarana pendidikan akhlak yang baik yaitu dapat dilihat dari bagaimana Rasulullah SAW dalam bersikap atau bertindak, Rasulullah menjadi suri teladan untuk ummatnya mampu dicontoh baik dalam ucapan maupun dalam segala bentuk tindakannya. Dikarenakan setiap apapun tindakan Rasullah SAW samahalnya menjadi apa yang diperintahkan Allah SWT. Rasulullah SAW merupakan suri teladan bagi ummat Islam, sehingga setiap ummatnya harus mampu mencontoh atau meneladani dari semua hal yang pernah dilakukan oleh Rosululloh SAW. Kepribadian Nabi Muhammad SAW adalah contoh yang sangat tepat untuk dijadikan referensi dalam pembentukan kepribadian dapat dilihat dari cara rasullulah memberikan didikan kepada anak-anaknya. Dengan begitu, melalui suri tauladan rasulullah memberikan sumbangsih yang sangat tinggi terhadap pembentukan akhlak kepada anak usia sekolah dasar. Tujuan dari penelitian ini ialah untuk mengetahuhi bagaimana Pembentukan Akhlak Melalui Suri Tauladan Rasullulah Pada Anak Usia Sekolah Dasar. Isi dari penelitian ini yaitu tentang 1) Upaya rasulullah mendidik anak-anaknya dalam keluarganya 2) Implementasi pembentukan akhlak melalui suri tauladan rasulullah pada anak usia sekolah dasar.
\end{abstract}

\section{PENDAHULUAN}

Memberikan sebuah pendidikan akhlak yang baik terhadap anak dari usia dini sangatlah penting. karena, pada daur kehidupan insan, masa kanak-kanak ialah sebuah masa yang paling penting, sekaligus merupakan masa yang sangat 
berbahaya. Bilamana tidak diberikan pembelajaran atau diperhatikan secara sahih, maka nanti seorang anak akan tumbuh dengan keadaan akhlak yang kurang baik. Dikarenakan, seseorang anak pada fitrahnya sudah diciptakan menggunakan kemampuannya buat mendapatkan kebaikan juga keburukan (Zamroni 2017). Sejalan dengan Kebutuhan pada pendidikan adalah perihal yang tidak bisa dipungkiri kembali, bahkan semuanya itu adalah hak dari semua warga Negara, Berkaitan dengan hal ini, dalam Undang-Undang Dasar (UUD) 1945 Pasal 31 ayat (1) secara tegas disebutkan bahwa; "Tiap-tiap warga Negara berhak mendapat pengajaran". Tujuan pendidikan nasional dinyatakan dalam Undang-Undang (UU) RI Nomor 20 Tahun 2003 Pasal 3 bertujuan buat berkembangnya potensi siswa agar menjadi insan yang beriman dan bertaqwa pada tuhan yg Maha Esa, berakhlak mulia, sehat, berilmu, cakap, kreatif berdikari, dan sebagai masyarakat Negara yang demokratis serta bertanggung jawab (Kuswanto 2015).

Hal ini terjadi karena Akhir-akhir ini hangat terjadi yang termasuk kedalam penurunan akhlak anak dimana seorang siswa mendapat sorotan telah melawan guru pada saat pembelajaran dikelas hal ini dapat dilihat siswa yang kehilangan etika atau sopan santun kepada teman sebaya, dan terhadap orang yang lebih tua darinya, dari sinilah perlu disampaikan bahwa yang terpenting adalah menumbuhkan nilai-nilai santun,berakhlak mulia, mulai tercipta kebiasaan saling mengejek dan menghina. Ini sebenarnya bukan mencerminkan kedalam akhlak yang mulia akan tetapi lebih merusak akhlakul karimah anak dari perilaku-perilaku yang tak sepantasnya dilakukan, apalagi sekarang yang masih menggemparkan dunia pendidikan saat ini banyaknya anak usia sekolah dasar yang kecanduan games online,tidak hanya hitungan menit akan tetapi anak bisa berjam-jam saat bermain game online, yang paling buruknya lagi anak tidak mau berangkat kesekolah hal ini yang mengakibatkan siswa menjadi malas belajar, anak sering berkata kasar, tidak mau menjalankan perintah orang tuanya seperti mengaji dan sholat sehingga mengakibatkan orang tua geram dengan perilaku anak. Hal ini, dapat disimpulkan bahwa ada penurunan akhlak yang dimiliki oleh seorang anak sekolah dasar setelah dilihat dari masalah-masalah yang telah diungkapkan melalui penelitian yang dilakukan dan oleh sebab itu perlunya pembentukkan akhlak yang harus dibentuk melalui keteladanan rasulullah (Mukminan 2017).
Pada dasarnya problem akhlak menerima perhatian yang primer pada ajaran Islam, sebab betapa pentingnya akhlak, galat satu tugas Nabi Muhammad SAW merupakan untuk memperbaiki akhlak insan, agar insan mempunyai sikap yang lebih baik pada melakoni kehidupan di global. Masih terdapat rakyat yang terindikasi krisis akhlak, hal ini tercerminkan dari banyaknya sekali perkara yang dilakukan oleh sebagian warga dimuat di media cetak maupun media elektronika. Akhlak menjadi sesuatu sumber kekuatan asal pada diri yang dikombinasikn antara kesamaan pada sisi baik dan sisi buruk. Pada hakikatnya akhlak tidak bisa disama artikan dengan menggunakan etika, jika etika itu berhubungan dengan nilai sopan santun antara sesama insan serta lebih dominan berhubungan dengan sikap lahiriyah, sehingga akhlak memiliki makna yg lebih luas, termasuk sikap batin juga pikiran. (Setiawan 2017).

Sebagai contoh dapat dilihat dari rasullulah mendidik anak-anaknnya dengan memperlihatkan Suri Teladan yang Baik. Keteladanan dalam sebuah pendidikan ialah cara yang berpengaruh serta terbukti paling berhasil pada mempersiapkan serta membuat aspek ethical, religious, serta etos sosial anak Rasulullah SAW memerintahkan kepada kedua orang tua buat menjadi suri teladan yang baik dalam bersikap serta berprilaku amanah dalam berafiliasi menggunakan anak. Seorang anak akan lebih memperhatikan serta meneladani sikap serta sikap orang dewasa. apabila mereka melihat ke 2 orangtua berperilaku jujur, mereka akan tumbuh pada kejujuran dan seterusnya. Untuk itu setiap orangtua diberikan tuntutan buat sebagai suri teladan yang lbeih baik bagi anak-anaknya. karena, seorang anak yang berada di masa pertumbuhan lebih memperhatikan sikap serta ucapan kedua orangtuanya (Kamisah).

Pembentukan Akhlak yang baik bagi anak akan terasa diharapkan, yaitu di waktu manusia dizaman terbaru ini diperlihatkan pada persoalan akhlak yg relatif berfokus, yang jika hal ini tetap dibiarkan saja dapat menghancurkan masa depan bangsa. Orang tua seharusnya lebih waspada terhadap ancaman-ancaman arus globalisasi yang akan menggerus kepribadian anak. Bahwa salah satu timbulnya krisis akhlak yang terjadi dalam rakyat ialah karena lemahnya supervisi sebagai akibatnya respon terhadap kepercayaan kurang. Krisis akhlak tersebut mengindikasikan wacana kualitas pendidikan agamanya yg seharusnya memberi nilai spiritual 
namun justru tidak memiliki kekuatan karena kesadaran pada beragama kurang (Manan 2017)

Jadi pada dasarnya khulq (budi pekerti atau akhlak) merupakan suatu keadaan yg telah meresap dalam jiwa dan menjadi keperibadian, sampai asal situ timbullah berbagai macam perbuatan yg secara impulsif serta mudah tanpa dibuat-buat dan tanpa memerlukan pemikiran. bila asal keadaan tersebut muncul tindakan laris yg baik dan terpuji berdasarkan sudut pandang syariat dan logika, maka hal ini dikatakan telah memiliki akhlak atau budi pekerti mulia. Namun sebaliknya apabila yg lahir artinya kelakuan yg jelek yang bertentangan dengaan syariat Islam dan istiadat-tata cara yg terdapat pada warga , maka dia sudah melakukan perbuatan tercela dan tidak berakhlak. Dengan begitu pembentukan akhlak dapat diartikan menjadi usaha sungguh-benar-benar dalam rangka menghasilkan eksklusif, dengan memanfaatkan sarana pendidikan dan pembinaan yang terprogram baik serta dilaksanakan menggunakan sungguhsungguh dan konsisten. Pembentukan akhlak ini dilakukan sesuai asumsi bahwa akhlak adalah yang akan terjadi perjuangan pembinaan, bukan terjadi menggunakan sendirinya. Potensi rohaniah yang ada pada diri insan, termasuk didalamnya logika, nafsu amarah, nafsu syahwat, fitrah, istilah hati, hati nurani dan bisikan hati dibina secara optimal menggunakan cara dan pendekatan yg tepat (Sahlan 2012). Sedangkan Secara etimologi akhlak memiliki beberapa istilah, yang telah disebutkan oleh banyknya tokoh antara lain adalah: Pertama, Ibn Maskawaih bahwa khuluq atau akhlak ialah keadaan gerak jiwa yang mendorong untuk melakukan perbuatan-perbuatan menggunakan tanpa memerlukan pemikiran (Ibn Maskawaih:25), kedua, al-Ghazali bahwa khuluk atau akhlak merupakan keadaan jiwa yang menumbuhkan perbuatan menggunakan simpel tanpa perlu berfikir terlebih dahulu. (Al-Ghazali:48) Ketiga, Ahmad Amin bahwa akhlak adalah kehendak yg dibiasakan. Maksudnya, Bila kehendak tadi membiasakan sesuatu, maka norma itu tersebut akhlak (Sahlan 2012). Pendapat lain mengemukakan dari segi Etimologi ialah sebagai berikut: Uswatun Hasanah merupakan "Suri teladan yg baik". 2 dalam buku kamus istilah kepercayaan bahwa Uswatun Hasanah yaitu sikap hidup yg baik serta diridhai oleh Allah SWT. Sebagaimana yang telah dicontohkan sang Rasulullah SAW (Huda and Afrina 2020).

Menurut UUSPN No 20 Tahun 2003 perjuangan sadar serta terjadwal untuk terciptanya suasana belajar serta proses pembelajaran agar siswa secara aktif menyebarkan potensi dirinya buat memiliki kekuatan spiritual keagaaman , pengendalian diri, akhlak mulia, dan keterampilan yang diharapkan dirinya, masyarakat bangsa serta Negara. Sedangkan Akhlak merupakan jamak asal khuluqan yang berarti tindakan , pengertian lain berkata perbuatan yang telah tertanam kuat pada jiwa seorang sebagai akibatnya menjadi kepribadian (Yanti 2020). M. Ngalim Purwanto, berkata bahwa pada aneka macam hal dalam sebuah pendidikan, keteladanan seorang pendidik merupakan suatu cara pendididikan yg sangat penting, bahkan yang paling utama. mirip yang ada dalam ilmu jiwa, dapat diketahui bahwa anak-anak sudah mempunyai dorongan meniru, serta suka mengidentifikasikan diri terhadap orang lain atau tingkah laris orang lain, terutama terhadap orang tua serta gurunya. Sebagaimana Rasulullah diutus oleh Allah menjadi suri teladan, sebagaimana firman Allah SWT:

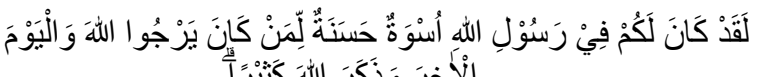

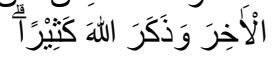

"Sungguh, telah ada pada (diri) Rasulullah itu suri teladan yang baik bagimu (yaitu) bagi orang yang mengharap (rahmat) Allah dan (kedatangan) hari Kiamat dan yang banyak mengingat Allah" (QS. alAhzab:21)40.

Ayat ini artinya yaitu meneladani Rasulullah saw. baik dalam segiucapan, tingkah laku juga perlakuannya. Arti dari ayai ini adalah perintah Allah pada insan supaya meneladani Rasulullah SAW. Intinya ayat tadi memberikan pada eksklusif Rasulullah, menggunakan demikian, pribadi Rasulullah SAW hendaknya wajib dimiliki oleh seseorang pendidik, ini berarti seorang pengajar atau orang tua memiliki peranan krusial pada menghasilkan jiwa anak. Sifat sabar, teguh pendirian, akhlakul karimah merupakan sifat yang wajib ditanamkan kepada murid mereka. sehingga mereka akan memiliki jiwa dan mental yang bertenaga dengan kepribadian yg baik (Munjid and Al 2017). Pada kamus bahasa Indonesia, keteladanan berasal dari unsur kata teladan berarti "hal (suatu perbuatan) yang wajib ditiru". sebab itu, keteladanan berarti meniru atau menconto. Sedangkan pada Bahasa Arab, keteladaan sinonim dengan terma al-qudwah dan al-uswah. Al-Qudwah atau al-qidwah secara literal-etimologis (lughatan), berarti suatu yg layak buat ditirukan atau diteladani (li mâ 
yuqtadâ bihi) samahalnya pula dengan term aluswah atau al-iswah, secara literal-etimologis pula berarti mengikuti atau meneladani dan berlaku sepertinya (yaqtadî bihi wa kâna fî mitsl hâlihi) (Maya 2017).

Istilah keteladanan dipahami dengan contoh yang baik. Sedangkan contoh yang baik adalah berdasar pada Rasulullah Muhammad Saw, yang dikenal dengan istilah uswatun hasanah. Istilah uswatun hasanah (bahasa Arab)yang berarti contoh yang baik, dalam bahasa Indonesia difahami sebagai keteladanan. Uswatun hasanah merupakan salah satu istilah dalam agama islam(al-Qur'an) yang dijadikan rujukan jika berbicara soal keteladanan. Di dalamnya mengandung beberapa pengertian, baik dari segi dari segi terminologi maupun etimologi. Ditinjau dari segi Terminologi sebagaimana yang dikemukakan oleh Ar-Raghib dalam Tafsir Ruhul Bayan. Rasulullah merupakan contoh teladan yang baik, sebagaimana yg tertulis pada surah Al-Ahzab ayat 21 secara zahir pada lafazh ayatnya, yaitu pada istilah uswatun hasanah, istilah uswatun berarti teladan dan hasanah berarti baik. Cara mengartikan kata uswatun hasanah secara utuh, dapat kita lihat berasal susunan pungkasnya, bahwa susunan katanya ditulis pada bentuk na'at man'ut yg berarti cara menerjemahkannya dengan menjadikan istilah hasanah menjadi kata sifat bagi istilah uswatun, sebagai akibatnya diartikan menggunakan penambahan kata "yang" diantara arti kedua kata tersebut.(Huda and Afrina 2020) .

Menurut Andi Setiyawan dan Fu`ad Arif Noor adalah Menanamkan nilai-nilai akhlakul karimah pada diri peserta didik tidak semudah membalik telapak tangan, diperlukan suatu tahapan yang disusun secara sistematis dan berkelanjutan. Melalui pendekatan historis peserta didik diajarkan akhlaqul karimah menggunakan metode qisah atau bercerita. Misal pada pembelajaran akidah akhlaq kelas bawah seperti kelas satu ketika guru mengenalkan pada anak perilaku jujur dan berkata baik maka dalam penyampaiannya dapat menggunakan cerita melalui kilas balik sejarah, ceritakan kepada anak bagaimana tauladan kita, Rasulullah SAW dalam berkata, bertindak, bahkan dalam berdagang (Setiyawan and Noor 2021). Sedikit tidak sama dengan penelitian yg sudah dilakukan sang Andi Syahraeni, menanamkan nilai syariat Islam pada anak dan keteladan yang diberikan orang tua adalah metode yang lebih efesiensi. sebab pendidikan dengan keteladanan tidak hanya memberikan suatu percontohan secara ekspresi, bagaimana konsep ihwal akhlak baik dan jelek, tetapi memberikan model secara eksklusif pada mereka. karena terbiasa mengikuti tindakan yang dilakukan oleh seorang guru atau pendidiknya. Hal ini secara psikologis seorang anak lebih cenderung senang meniru atau mengkuti perihal yang baik dan buruk. Sifat anak didik seperti itu diakui oleh Islam. Umat Islam meneladani Rasulullah saw. Rasul meneladani al Quran. Aisyah R.A. pernah berkata, bahwa akhlak Rasul itu merupakan al Quran. Pernyataan Aisyah itu sahih, sebab memang eksklusif rasul itu adalah interpretasi al Quran secara nyata, tidak hanya cara beribadah, cara kehidupan sehari-harinya pun kebanyakan artinya model tentang cara kehidupan yang islami (Syahraeni 2015).

Berdasarkan hasil penelitian yang dilakukan oleh para peneliti, terdapat suatu perbedaan yang lebih signifikan dengan penelitian ini yaitu kajian dalam penelitian ini ingin mendeskripsikan secara mendalam tentang bagaimana upaya rasulullah dalam mendidik anak-anaknya dan bagaimana implimentasi pembentukkan akhlak melalui suri tauladan rasulullah pada anak sekolah dasar. Sehingga, tujuan dari penelitian ini untuk mengetahui bagaiamana mendidik dengan cara yang dilakukan rasullulah dalam pembentukkan akhlak anak-anaknya dalam keluarga dari situlah dapat dilihat akhlak yang bagaimana yang bisa diterapkan kepada anak usia sekolah dasar.

\section{METODE PENELITIAN}

Dalam penelitian ini, peneliti menggunakan Metode kualitatif. Penggunaan Metode kualitatif ini oleh peneliti untuk menganalisis perseteruan yg terdapat. Metode kualitatif merupakan suatu cara dalam melakukan sebuah penelusuran, pengamatan secara intensif menggunakan mekanisme ilmiah buat membuat kesimpulan dalam bentuk naratif berdasarkan analisis data. Pendekatan dalam penelitian yang digunakan oleh peneliti yaitu pendekatan studi kepustakaan atau library research. Pendekatan ini adalah sebuah penelitian yang sumber informasinya berasal artikel ilmiah, banyak sekali sumber asal internet atau kepustakaan, dan lain sebagainya pada penelitian ini data dihasilkan melalui teknik pengumpulan data yg bersumber asal artikelartikel ilmiah, karena itu metode pengumpulan data dilakukan dengan penelitian (library research) kepustakaan (Ahmad 2020). Metode ini digunakan oleh peneliti dengan jalan membaca, mengkaji buku atau kitab serta menginterprestasi artikel yang berkaitan dengan tema 
penelitian ini. Teknik pengumpulan data pada penelitian ini adalah pengumpulan data literer yaitu mengumpulkan bahan-bahan pustaka yang masih ada kaitannya dengan objek pembahasan yang akan diteliti. Data yang telah ada pada kepustakaan tersebut dikumpulkan serta diolah hingga penemuan hasil penelitian (Siahaan 2016).

\section{HASIL DAN PEMBAHASAN}

A. Upaya Rasulullah Mendidik Anak-Anaknya Dalam Keluarga

Sebagaimana diketahui, Rasulullah memiliki 13 istri: Khadijah binti Khuwailid, Saudah binti Zam'ah, Aisyah binti Abu Bakar, Hafshah binti Umar, Zainab binti Khuzaimah, Hindu binti Abi Umayyah, Zainab binti Jahsy, Raihanah binti Al-Harits, Ramlah binti Abu Sufyan, Shaf Putra-putri Rasulullah, yaitu keturunan Khadijah binti Khuwailid, yaitu Qosim, Thayyib, Tahir, Ruqiyah, Zainab, dan Umm Kulthum, dapat diamati dari istri Nabi. Rasullulah memiliki tujuh putra dan putri, menurut karya Ibn Hisyam: Abdullah, Qasim, Ruqaiyah, Zainab, Ummu kultsum, dan Fatimah. (AK.Mustafit 2004)

Karena seorang anak adalah anugerah dari Allah SWT, maka perlu bagi seorang ayah untuk merawatnya dengan sebaik-baiknya. Kesalahan ketiga adalah mengganti sekolah dengan waktu yang dihabiskan untuk mempersiapkan diri menjadi orang yang intelektual dan berperilaku baik. Tentu saja, karena Nabi diajarkan menyanyi, ia menjadi panutan yang luar biasa bagi pendidikan anak-anak. Yang terkenal simpatik, sabar, dan tidak suka meneriaki anak-anak, tetapi keras dalam urusan agama dan hal-hal lain. Dari Aisyah berkata, Rasulullah Shallallau alaihi wasallam bersabda:

"Sebaik-baik kalian adalah (suami) yang paling baik terhadap keluarganya dan aku adalah yang paling baik terhadap keluargaku." (HR.Tirmidzi).

Sesuai dengan hadis Rasulullah Șallallāh 'alayh wa Sallam:

"Anak adalah raja selama tujuah tahun pertama dan hamba pada tujuh tahun kedua, serta teman musyawarah pada tujuh tahun ketiga".

menurut hadits Nabi allallh 'alayh wa Sallam. Menurut siklus kehidupan, orang tua memiliki tanggung jawab utama untuk pendidikan anak-anak mereka, termasuk pengembangan karakter dan kepribadian, dan harus bekerja keras untuk mengawasi perilaku mereka dengan menanamkan sikap positif dan cita-cita luhur. Misalnya, ketika anak-anak menunjukkan kecenderungan buruk seperti arogansi, ibu-ibu yang arogan segera menanganinya karena kebiasaan ini pada akhirnya akan menyusup ke dalam jiwa anak-anak. Sangat sulit untuk memperlakukan bantuan, seperti pohon yang akarnya telah tenggelam ke dalam bumi. (Gade 2012)

Alangkah indahnya cara Rasulullah SAW mendidik anak, ketika memiliki anak adalah cita-cita setiap pasangan, dengan menitipkan kewajiban tersebut kepada hambanya, yang harus dipersiapkan untuk mengasuh dan mengasuh anak dengan sebaik-baiknya. Dia telah memberikan contoh yang sangat baik dalam mendidik anak-anak, seperti yang diperintahkan oleh Nabi Shallallahu 'alaihi wasallam. Berikut 13 cara Nabi Muhammad mendidik anak laki-laki dan perempuan dalam rumah tangga. Dia terkenal penyayang, perhatian, dan sabar, dan dia tidak suka berteriak pada anak muda. Namun, dia tegas dalam halhal agama:

1. Tidak mengekang anak bermain

Diriwayatkan dari Anas bin Malik, ia berkata:

"Pada suatu hari aku melayani Rasulullah. Setelah tugasku selesai, aku berkata dalam hati, Rasulullah pasti sedang istirahat siang. Akhirnya, aku keluar ke tempat anak-anak bermain. Aku menyaksikan mereka sedang bermain. Tidak lama kemudian, Rasulullah datang seraya mengucapkan salam kepada anak-anak yang sedang bermain. Beliau lalu memanggil dan menyuruhku untuk suatu keperluan. Aku pun segera pergi untuk menunaikannya, sedangkan beliau duduk dibawah sebuah pohon hingga aku kembali." (HR. Ahmad).

Dari Aisyah, ia berkata:

"Aku dahulu pernah bermain boneka di sisi Nabi shallallahu alaihi wa salam. Aku memiliki beberapa sahabat yang biasa bermain bersamaku. Ketika Rasululah shallallahu alaihi wa salam masuk dalam rumah, mereka pun bersembunyi dari beliau. Lalu beliau menyerahkan mainan padaku satu demi satu lantas mereka pun bermain bersamaku." (HR. Bukhari).

Rasulullah pun mencontohkan beliau mengucpkan salam terlebih dahulu saat lehat hadapan anak-anak bahkan 
Rasulullah SAW ikut bermain, berbagi makanan, mencium, dan menggendong anak-anak ("Hadist Id," n.d.).

2. Mengajarkan ilmu tauhid

Rasulullah mendidik putra-putrinya dengan mengajarkan tauhid sebagai ilmu. Pengertian tauhid secara harafiah adalah "menyatukan" hakikat tauhid (sebagaimana didefinisikan oleh aqidah), yaitu kepercayaan akan adanya suatu kekuatan yang menciptakan, mengatur, dan menguasai alam semesta, yaitu Allah SWT. (Basri 2021). Ilmu tauhid merupakan ilmu wacana ketuhanan. Tentunya, ilmu ini sangat krusial buat diajarkan pada anak sejak dini. Sebagaimana yang dilakukan sang Rasulullah, beliau mengajarkan anakanaknya buat mengucapkan "Lailaha illaallah" yg artinya tidak terdapat dewa selain Allah. berasal Ibn Abbas, Rasullullah bersabda:

"Bukalah lidah anak-anak kalian pertama kali dengan kalimat "Lailahaillaallah". Dan saat mereka hendak meninggal dunia maka bacakanlah, "Lailaha-illallah. Sesungguhnya barang siapa awal dan akhir pembicaraannya "Lailah-illallah", kemudian ia hidup selama seribu tahun, maka dosa apa pun, tidak akan ditanyakan kepadanya." (sya'bul Iman).

Bahwa Allah adalah satu-satunya dan Tuhan yang sejati. Semua jenis pengabdian hanya kepada Allah. Bahwa Allah adalah pertolongan yang hakiki, dan bahwa manusia wajib semata-mata meminta pertolongan kepada-Nya. Anak muda memahami bahwa ini adalah panggilan untuk bantuan dari orang lain selain Allah, dan bahwa Allah-lah yang memimpin dan memerintahkan disan dalam mengarungi kehidupan dunia yang penuh dengan rintangan, masalah, dan godaan. (Khairil 2015).

\section{Mengajarkan ilmu agama}

Anak-anak juga diberikan informasi agama oleh Nabi Muhammad sejak usia dini. Karena jika seorang anak tidak diberikan pendidikan sejak usia dini, hanya masalah waktu sampai ia terpengaruh oleh lingkungannya dan mengambil jalan yang salah. Pengetahuan teologis Rasul kepada putranya diragukan luas, tetapi itu diberikan secara bertahap.

4. Mengajarkan tata cara sholat

Rasulullah bersabda:

"Perintahlah anak-anak kalian untuk shalat ketika mereka berusia tujuh tahun dan pukullah mereka jika enggan melakukannya pada usia sepuluh tahun, dan pisahkanlah tempat tidur mereka." (HR. Ahmad)

Rasulullah sudah memberikan bahwa usia mengajarkan anak belajar kepercayaan (sholat) waktu sudah tujuh tahun, Ibadah Sholat dipandang sebagai suplemen untuk pembentukan iman Islam. Karena ibadah adalah pondasi iman. Ibadah, di sisi lain, adalah refleksi yang dihasilkan dari demonstrasi iman. Ketika seseorang menyambut pintu masuk Tuhannya dan meminta petunjuk-Nya, dia mengundang impuls alami ke dalam hidupnya. Namun, untuk menjaga keimanan jiwa tetap subur, harus diairi dengan air ibadah dalam segala bentuk dan raganya. Inilah satusatunya cara iman dapat berkembang di hati dan menjadi kuat dalam menghadapi badai kehidupan. Dalam skenario ini, penting untuk mengingat arahan dasar Nabi Muhammad saat mengajarkan prinsip-prinsip doa, yaitu: Kelas satu ini memiliki beberapa strata, antara lain strata perintah shalat, shalat anak, tingkatan komando shalat disertai pemukulan, melatih anak shalat, khususnya menyuruh lakilaki melaksanakan shalat Jumat, mengajak anak shalat malam, melatih anak shalat. istikharah, menemani anak saat salat Idul Fitri, mengajak anak ke masjid, melatih anak sekolah, dan mengajar haji.(Kamisah and Herawati 2019)

\section{Mengajarkan ibadah puasa}

Diriwayatkan berasal Ar-Rubayyi bintu Muawwidz, keliru satu perempuan shalehah teman rasul. dia berkata:

"Kami menyuruh puasa anak-anak kami. Kami buatkan untuk mereka mainan dari perca. Jika mereka menangis karena lapar, kami berikan mainan itu kepadanya hingga tiba waktu berbuka." (HR. Al-Bukhari dan Muslim).

Puasa adalah momentum buat pembetukan karakter bangsa. Puasa akan melahirkan manusia-manusia yang mempunyai 
prinsip andal, kesabaran, keiklasan serta tidak pantang menyerah serta memiliki solidaritas serta saling mencintai satu sama lain (Ahmad 2020).

\section{Mengajarkan bacaan doa-doa harian}

Nabi juga mengajarkan anak-anak muda untuk membaca doa harian secara teratur. Sholat bercermin, sholat keluar masuk WC, sholat sebelum dan sesudah makan, sholat diluar rumah, dan lain sebagainya adalah contoh-contoh sholat. Ini tentu sangat penting agar Allah Ta'ala selalu melindungi kita dan menjaga kita dari bahaya. (Bahar et al. 2020).

7. Mengajarkan anak untuk berbakti kepada orang tua

Rasulullah SAW selalu mengajarkan pada anak-anaknya perihal berbakti pada orang tua. sebab anak durhaka dalam islam adalah perbuatan dosa besar (Kamisah and Herawati 2019).

8. Berlaku adil kepada anak perempuan dan laki-laki

Rasulullah tidak pernah membedabedakan antara anak laki-laki serta perempuan. Bukan berarti anak laki-laki derajatnya lebih tinggi asal perempaun ataupun kebalikannya. pada suatu hadist dijelaskan dari Nu'man bin Basyir, dia pernah tiba kepada Rasulullah kemudian bersabda:

"Sungguh, aku telah memberikan sesuatu kepada anak laki-lakiku yang dari Amarah binti Rawwahah, lalu Amarah menyuruhku untuk menghadap kepadamu agar engkau menyaksikannya, ya Rasulullah." Lalu Rasulullah bertanya; "Apakah engkau juga memberikan hal yang sama kepada anak-anakmu yang lain?" Ia menjawab, "Tidak."

Rasulullah bersabda:

"Bertakwalah kamu kepada Allah dan berlaku adillah kamu diantara anakanakmu." Nu'man pun mencabut kembali pemberiannya." (HR. Bukhari) (Tambak 2019).

9. Mendidik anak dengan akhlak mulia

Rasulullah adalah orang yang paling berbudi luhur di planet ini. Dia dikirim untuk meningkatkan perilaku manusia. Akibatnya, ia menanamkan konsep kasih sayang pada anak-anak setiap saat, terlepas dari tanggalnya. (Manan 2017).

10. Mengajarkan cara berpakaian yang sesuai syariat agama islam

Bagi anak perempuan , Rasulullah SAW menyampaikan pendidikan tentang bagaimana muslimah yang baik dengan cara berpakaian secara islami. Yaitu memakai pakaian longgar dan berjilbab syar'i.

"Wahai Nabi, katakanlah kepada isteriisterimu, anak-anak perempuanmu dan isteri-isteri orang Mukmin hendaklah mereka mengulurkan jilbabnya ke seluruh tubuh merek. Yang demikian itu supaya mereka lebih mudah untuk dikenal, karena itu mereka tidak di ganggu. dan Allah adalah Maha Pengampun lagi Maha Penyayang." (QS. Al-Ahzab:59).

Diriwayatkan dari Aisyah, bahwa Asma binti Abi Bakar menemui Rasulullah SAW dengan kondisi ia berpakaian pendek. Kemudian berpalinglah Rasulullah SAW seraya berkata;

"Wahai Asma, sesungguhnya wanita apabila telah baligh tidak pantas terlihat kecuali ini dan ini (beliau menunjuk wajah dan kedua telapak tangannya)." (HR. Abu Daud).

11. Mengajarkan batasan pergaulan antara perempuan dan laki-laki

Cara Nabi Muhammad SAW mendidik anak juga meliputi pergaulan. Beliau mengajarkan tentang batasan-batasan berteman antara laki-laki dan perempuan, tentang pentingnya menjaga pandangan, tentang besarnya dosa zina dan sebagainya (Alawiyah, Handrianto, and Kania Rahman 2020).

12. Bersikap lemah lembut terhadap anak

Walaupun Nabi Muhammad SAW adalah pemimpin umat muslim. Namun, beliau tidak pernah sombong atau bersikap semena-mena terhadap keluarganya. Beliau justru menunjukkan akhlak yang baik dan lemah lembut, begitu juga kepada anak-anaknya. Nabi Muhammad sering memanggil mereka dengan sebutan yang indah, menggendong dan mengusap kepala mereka. Aqra bin Habis, pemuka Bani Tamim mengaku, "Demi Allah, aku mempunyai 10 orang anak, tetapi tak satu 
pun aku cium di antara mereka." Nabi pun memandangnya dan berkata; "Barang siapa yang tidak mengasihi, ia tidak akan dikasihi", tampak bahwa Raulullah SAW mengoreksi perilaku anaknya tanpa perlu berkata kasar, marah-marah, apalagi sampai menggunakan kekerasan fisik. Disisi lain, fatimah sebagai anaknya juga memiliki kepekaan dalam memahami suasana hati orang tuanya. Fatimah sejak kecil didik oleh orang rasulullah untuk terbiasa memiliki rasa malu untuk berbuat salah dan enggan melakukan hal-hal yang bertentangan. Pada akhirnya, kasih sayang dapat menjadi cara efektif untuk mendidik anak (Umroh 2019).

\section{Memberikan hadiah}

Rasulullah pernah membariskan Abdulullah, Ubaidillah serta sejumlah anak-anak pamannya, Al Abbas, pada suatu barisan, lalu beliau bersabda:

"Siapa yang paling dahulu sampai kepadaku, dia akan mendapatkan (hadiah) ini. Mereka pun berlomba lari menuju tempat Rasulullah berada. Setelah mereka sampai di tempat beliau, ada yang memeluk punggung dan ada pula yang memeluk dada beliau. Rasulullah menciumi mereka semua serta menepati janji kepada mereka." (Majmu'uz Zawaid) (Haq Azhar 2018).

B. Implementasi pembentukan akhlak melalui suri tauladan rasulullah pada anak usia sekolah dasar.

Metode keteladanan dapat diberikan untuk terbentuknya akhlak yang melalui beberapa tahapan. Keteladanan artinya metode yang terdapat pada pembelajaran menggunakan strategi prihal mencontohkan sesuatu terhadap siswa, baik juga pada perkataan. Khususnya pada anak sekolah dasar senang mengikuti yang orang dilakukan pada lingkungan sekitarnya (Khomsiyatin, Iman, and Ariyanto 2017). Hal yang ditiru itu merupakan sikapsikap yang dicontohkan atau dilaksanakan oleh orang yang menjadi idolanya atau seseorang yang dihormatinya (Sitompul 2018). Demikian, pentingnya dalam pendidikan yang menjadi keteladanan yang sangat ampuh untuk perkembangan siswa dan keteladanan itu terletak pada diri Rasulullah, yang bisa menjadi tujuan terhadap pendidik menjadi contoh primer.(Karo 2016).
Dalam pembentukkan akhlak melalui suri tauladan rasulullah untuk mencapai kesuksesan ketika mentransfer keteladanan tidak lepas dari contoh (taqlid, imitation) yg sebagai ciri manusia artinya melakukan suatu tindakan sebagaimana yg dilakukan oleh orang lain. Melalui sifat ini ialah satu pembawaan dasar manusia. Pemberian contoh ini terpusat di tiga unsur. Pertama, mencontoh serta menirukan. Ini tampak jelas pada anakanak, dimana anak tidak mendengarkan nasehat atau petunjuk serta menirukan gaya berkata-kata, cara berjalan, menirukan pakaian yang dipakai atau prilaku lain berawal oleh seseorang yang disenangi. sebab itu, anak-anak biasa meniru pemimpin, pembesar, orang tua serta guru (Hidayat 2015).

Berdasarkan hasil dari penelitian bahwa telah diketahui bagaimana upaya rasulullah mendidik anak-anaknya dalam keluarga yaitu terdapat 13 cara rasulullah mendidik anakanaknya, diantaranya: tidak mengekang anak bermain, mengajarkan tata cara sholat, mengajarkan ilmu agama, mengajarkan tata cara sholat, mengajarkan ibadah puasa, mengajarkan bacaan doa-doa, mengajarkan anak untuk berbakti kepada orang tua, berlaku adil kepada anak perempuan dan anak laki-laki, mendidik anak dengan akhlak mulia, mendidik anak dengan mengajarkan cara berpakaian sesuai syariat ajaran agama islam, mengajarkan batasan pergaulan antara perempuan dengan laki-laki dan bersikap lemah lembut. Dari ke 13 cara rasulullah mendidik anak-anaknya ini sangatlah patut diajarkan pada anak usia dini apalagi untuk anak diusia sekolah dasar.

Implementasi yang dapat dimbil dari upaya rasulullah yang dapat diterapkan untuk anak usia sekolah dasar yang paling utama adalah diperlukan peran guru dalam lingkungan sekolah dan peran orang tua saat anak berada lingungan dirumah untuk menunjang akhlak yang dimiliki anak. Peran orang tua dalm pembentukkan akhlak anak sekolah dasar. Membuat anak berakhlak mulia atau berkarakter tidak hanya dilakukan menggunakan istilah-kata atau perintah saja, akan tetapi wajib dengan contoh teladan asal orang tua ataupun pendidik. Para ahli pendidikan serta psikologi mengatakan bahwa anak akan menirukan apa yang dilakukan sang orang tua ataupun para pendidiknya, selain itu Rasulullah menanamkan perilaku yang kelak 
menjadi contoh kepada seluruh umat manusia, khususnya kepada orang Islam. Berdasarkan uraian tersebut maka dapat disimpulkan bahwa keteladanan yang baik adalah jika berpola ketauladanan tersebut kepada bagindan Rasulullah. Maka patut ditiru dan dicontoh dalam situasi dan kondisi, setiap ketika yang dapat berubah-ubah tanpa merubah prinsip dan dasar-dasar yang dicontohkan itu Rasulullah SAW (Rochmawati 2018). Karena itu, terbentuknya akhlak yang baik itu haruslah orang tua membentuk anak sejak didalam.Pembiasaanpembiasaan tadi akan terpatri pribadi dalam hati anak. Semakin banyak pembiasaan baik yang dilakukan semenjak kecil, semakin baik pula akhlaknya nanti ketika ia dewasa. Adapun implimentasi dari pembentukan akhlak melalui suri tauladan yang menjadi kewajiban orang tua dan guru dalam pembentukkan akhlak anak berdasarkan yang telah rasulullah contohkan dari rasulullah mendidik anak-anaknya dalam keluarga (Fitri 2017).

Mengajari doa-doa pada anak, dikerena doa bisa dijadikan keamanan dan tembok bagi jiwa serta raga, bahkan sebagai bentuk ibadah yang sangat praktis serta sangat dalam betapa besarnya tanggung jawab orang tua dalam mengajarkan serta mendidik anak-anak, dengan cara mengajarkan menulis, membaca serta mengafal doa-doa, sebab doa ialah jantungnya ibadah (Dhin 2020). Ibadah lainnya yaitu anak-anak diajarkan untuk sholat ketika anak telah mulai pintar sholat, maka kewajiban selanjutnya bagi orang tua terhadap anaknya memerintah sholat waktu anak sewaktu berumur tujuh tahun, dan mempertegas anak yang sudah sepuluh tahun tetapi masih meninggalkan sholat. Pertarungan ini sebagai tanggung jawab orang tua buat menyuruh anaknya taat pada Allah berasal sejak kecil, Bila anak telah mumayiz masih acapkali meninggalkan sholat wajib ditindak tegas, walaupun wajib di pukul dengan pukulan mendidik serta tak menyakiti hati dan mental anak-anaknya.Tanggung jawab orang tua juga memisahkan anak laki-laki dengan wanita dengan kamar yang tidak sama, menjadi bentuk pelatihan kearah kemandirian dan tanggung. kasus perintah mengajarkan serta menyuruh anak supaya mau sholat serta rajin sholat, itu adalah perjuangan serta ikhitar, tentu wajib ditopang sebagaimana doa nabi Ibrahim Alaihi Salam pada al-Qur'an surah Ibrahim ayat 40 yang ialah:
"Ya Tuhanku, jadikanlah aku serta anak cucuku orang-orang yang permanen mendirikan Sholat"

Wajib bagi orang tua mengajarkan ibadah puasa kepada anaknya agar anak memiliki jiwa mandiri dan sanak mengetahui bagaimana meraakan kesusahan sebagai orang yang berkekurangan sekaligus membentuk sifat emosi yang dimiliki anak. Hal ini harus segera dilaksanakan orang tua mengajarkan keutamaan puasa menjadikan wujud merangkai rukun Islam yang ke tiga (puasa) (Nurhadi 2019).

Akhlak tidak akan pernah ada tanpa diajarkan, serta membiasakan perlu adanya pembentukkan, oleh karena itu pembelajaran kepercayaan, dan menjadi ilmu dengan berurut dan juga wajib diikuti, secara berkelanjutan untuk pengalamannya. Orang tua memegang peran dalam krusial untuk aplikasi pendidikan agama untuk dirumah. tetapi orang tua diinginkan menjadi teladan dalam hal beribadah dan berakhlak (Angdreani, Warsah, and Karolina 2020). Pendidikan yang primer dan menjadi pertama artinya pembelajaran pada keluarga. pada hal ini dalam keluarga punya peran dalam membentuk akhlak anak, oleh sebab itu keluarga wajib menyampaikan pembelajaran atau mendidik anak. Wacana akhlak mulia atau baik, hal itu tercermin berasal dari perilaku serta sikap orang tua yang dapat dicontoh oleh anak. Pendidikan agama merupakan perjuang usaha secara otomatis serta realistis buat membantu mendidik anak supaya hidup mereka bisa menggunakan ajaran kepercayaan, dan suatu usaha bimbingan terhadap murid supaya nantinya bisa menjalankan ajaran agamanya. Dalam pendidikan kepercayaan yang lebih diutamakan merupakan menjadi pembentuk karakter anak, yaitu membentuk watak yang baik pada siswa. (Masrofah, Fakhruddin, and Mutia 2020).

Sama halnya ketika anak berada didalam sekolah yaitu dengan pembentukkan akhlak yang dilakukan para murid sebelum pelajaran dimulai membiasakan murid untuk membaca doa, memberi salam yang baik kepada guru, dan juga sahabat, mengahafal surat-surat pendek, shalat berjamaah pada saat disekolah, serta mengatakan hal sopan kepada pengajar juga teman seumuran. (Fahmi and Susanto 2018). 


\section{SIMPULAN DAN SARAN}

\section{A. Simpulan}

Dihakikatnya khulq atau budi pekerti atau akhlak ialah suatu keadaan atau sifat yang sudah meresap dalam jiwa, dan sebagai karakter, sampai dari situ tumbuh berbagai macam perilaku yang secara impulsif dan praktis tanpa didesain dan tanpa perlu pemikiran. Pembentukan akhlak dapat dibagi menjadi beberapa metode, salah satunya metode keteladanan. Dengan mendidik seperti (keteladanan) artinya suatu metode pendidikan yang dianggap akbar akibatnya. Segala yang diajarkan oleh Rasul pada kehidupannya, artinya cerminan pada isi alquran secara utuh. Pembentukkan akhlak melalui suri tauladan rasulullah pada anak usia sekolah dasar. mendukung hasil penelitian 1) Upaya rasulullah mendidik anak-anaknya dalam keluarganya yaitu terdapat Berdasarkan hasil dari penelitian bahwa telah diketahui bagaimana upaya rasulullah mendidik anak-anaknya dalam keluarga yaitu terdapat 13 cara rasulullah mendidik anakanaknya, diantaranya: tidak mengekang anak bermain, mengajarkan tata cara sholat, mengajarkan ilmu agama, mengajarkan tata cara sholat, mengajarkan ibadah puasa, mengajarkan bacaan doa-doa, mengajarkan anak untuk berbakti kepada orang tua, berprilaku adil terhadap anak laki laki dan anak perempuan, mendidik anak dengan akhlak mulia, mendidik anak dari cara berpakaian yang dengan sesuai syariat ajaran agama islam, membatasi pergaulan antara laki-laki dengan perempuan dan bersikap lemah lembut. 2) Implementasi pembentukan akhlak melalui suri tauladan rasulullah pada anak usia sekolah dasar.

\section{B. Saran}

Dari ke 13 cara rasulullah mendidik anakanaknya ini sangatlah patut diajarkan pada anak usia dini apalagi untuk anak diusia sekolah dasar. Semenjak anak masih kecil, harusnya orang tua telah memberikan serta mengajarkan dua kalimat syahadat, bersama artinya pada mereka. Hal ini bermanfaat buat memperkenalkan anak pada Allah serta RasulNya. supaya saat akbar mereka mempunyai landasan tauhid yang kuat. dengan landasan tauhid yang kuat, maka iman seseorang tidak akan runtuh dan tertipu menggunakan ekspetasi keduniawian tidak hanya orang tua yang berada dilingkaguru dengan cara mengajarkan ilmu tauhid dan ilmu agama diantaranya keyakinan terhadap adanya Tuhan, dan setiap perlakuan yg dilakukan oleh siswa. sebagai akibatnya kemudian, pembelajaran tauhid demikian bukanlah hanya sekedar mengetahui rukun tentang iman, nama dan juga sifat-sifat dewa. namun dengan pembelajaran dibidang studi tauhid memberikan peluang untuk tumbuhnya pencerahan perihal nilai-nilai dalam ketuhanan dan setiap prilaku para siswa.

\section{DAFTAR RUJUKAN}

Ahmad, Iqbal Faza. 2020. "Asesmen Alternatif Dalam Masa Darurat Penyebaran Coronavirus Disease ( Covid-19)." Jurnal Pedagogik 7, no. 01: 195-222.

\section{AK.Mustafit. 2004. Inner Beauty Istri-Istri Nabi} Muhammad SAW. Qultum Media.

Alawiyah, Syarifah, Budi Handrianto, and Imas Kania Rahman. 2020. "Adab Berpakaian Wanita Muslimah Sesuai Tuntunan Syariat Islam." Rayah Al-Islam 4, no. 02: 218-28. https://doi.org/10.37274/rais.v4i02.338.

Angdreani, Vebri, Idi Warsah, and Asri Karolina. 2020. "Implementasi Metode Pembiasaan: Upaya Penanaman Nilai-Nilai Islami Siswa SDN 08 Rejang Lebong." Jurnal Iain Bengkulu 19, no. 1: 1-21.

Bahar, H, I Iswan, V H Sundi, N L Fitri, and ... 2020. "Pembelajaran Beyond Centers and Circle Time (Bcct) Berbasis Al-Qur'an Dalam Peningkatan Nilai-Nilai Karakter Bagi Anak Usia Dini." ... Jurnal Pendidikan Anak ... 4, no. 2: 145-55. https://doi.org/https://doi.org/10.24853/ yby.4.2.145-155.

Basri, Hasan. 2021. "Integrasi Nilai-Nilai Tauhid Pada Pelajaran Sains Bagi Siswa Sekolah Dasar Islam Terpadu." Tadabbur: Jurnal Peradaban Islam 3, no. 1: 164-79. https://doi.org/10.22373/tadabbur.v3i1.15 3.

Dhin, Cut Nya. 2020. "Kepedulian Orang Tua Terhadap Pendidikan Agama Siswa." Jurnal Kinerja Pendidikan 2, no. 3: 565-77.

Fahmi, Muhammad Nahdi, and Sofyan Susanto. 2018. "Implementasi Pembiasaan Pendidikan Islam Dalam Membentuk Karakter Religius Siswa Sekolah Dasar." 
Pedagogia: Jurnal Pendidikan 7, no. 2: 8589. https://doi.org/10.21070/pedagogia.v7i2.1 592.

Fitri, Nur Lailatul. 2017. "Peran Orang Tua Dalam Membentuk Akhlak Anak Sejak Dini." AlHikmah: Indonesian Journal of Early Childhood Islamic Education 1, no. 2: 15568. https://doi.org/10.35896/ijecie.v1i2.11.

Gade, Fithriani. 2012. "Ibu Sebagai Madrasah Dalam Pendidikan Anak." Jurnal Ilmiah Didaktika 13, no. 1: 31-40. https://doi.org/10.22373/jid.v13i1.462.

"Hadist Id." n.d. In https://id.search.yahoo.com/search;_ylt=A wrxxP3Xe69h.TUAnxPLQwx.;_ylu=Y29sbwN zZzMEcG9zAzEEdnRpZAMEc2VjA3Fydw-$? \mathrm{p}=$ www.hadist.id\&type $=$ E210ID91215G0\& ei=UTF-8\&norw $=1 \& f r=$ mcafee.

Haq Azhar. 2018. "Motivasi Belajar Dalam Meraih Prestasi." Jurnal Pendidikan Islam Victratina 3, no. 1: 193-214.

Hasanah, Ainul. 2018. "Mengajarkan Shalat Pada Anak Melalui Metode Demonstrasi, Tanya Jawab Dan Pembiasaan." Al Hikmah: Indonesian Journal of Early Childhood Islamic Education 2, no. 1: 13-28.

Hidayat, Nurul. 2015. "Metode Keteladanan Dalam Pendidikan Islam." Ta'allum: Jurnal Pendidikan Islam 3, no. 2: 135-50. https://doi.org/10.21274/taalum.2015.3.2. 135-150.

Huda, Shofiah Nurul, and Fira Afrina. 2020. "Rasulullah Sebagai Role Model Bagi Pendidik." Fitrah: Journal of Islamic Education 1, no. 1: 72-88.

Kamisah, and Herawati. 2019. "Mendidik Anak Ala Rasulullah ( Propethic Parenting ) Educate Children with Rasulullah Method ( Propethic Parenting )." Journal of Education Science (JES) 5, no. 1: 33-42.

Karo, Tiy Kusmarrabb. 2016. "WAWASAN ALQURAN TENTANG METODE PENDIDIKAN Tiy Kusmarrabbi Karo." Jurnal Waraqat I, no. 2: 1-18.

Khairil, Muhammad. 2015. "Strategi Pendidikan Islam Nabi Muhammad SAW." Jurnal Studi Islam 10, no. 2: 88-121.
Khomsiyatin, Nurul Iman, and Ayok Ariyanto. 2017. "Metode Pendidikan Akhlak Pada Anak Usia Dini Di Bustanul Athfal Aisiyah Mangkujayan Ponorogo." Educan: Jurnal Pendidikan Islam 1, no. 2: 271-81. https://doi.org/10.21111/educan.v1i2.144 4.

Kuswanto, Edi. 2015. "Peranan Guru PAI Dalam Pendidikan Akhlak Di Sekolah." MUDARRISA: Journal of Islamic Education 6, no. 2 : 194. https://doi.org/10.18326/mdr.v6i2.194220.

Manan, Syaepul. 2017. "Pembinaan Akhlak Mulia Melalui Keteladanan Dan Pembiasaan." Jurnal Pendidikan Agama Islam -Ta'lim 1, no. 2: 49-65.

Masrofah, Tria, Fakhruddin Fakhruddin, and Mutia Mutia. 2020. "PERAN ORANG TUA DALAM MEMBINA AKHLAK REMAJA (Studi Di Kelurahan Air Duku, Rejang LebongBengkulu)." TA'DIBUNA: Jurnal Pendidikan Agama Islam 3, no. 1: 39. https://doi.org/10.30659/jpai.3.1.39-58.

Maya, Rahendra. 2017. "Pemikiran Pendidikan Muhammad Quthb Pemikiran Pendidikan Muhammad Quthb." Jurnal Edukasi Islami Jurnal Pendidikan Islam 06, no. 11: 1-16. http://journal.unair.ac.id/filerPDF/jpppaa5 c340a9efull.pdf.

Mukminan, Edy Surahman. 2017. "Talking with People about to Die." British Medical Journal 4 , no. 1: 1-13. https://doi.org/10.1136/bmj.3.5922.25.

Munjid, Kamus Al, and Al Maktabah Al. 2017. "Islam Dan Pendidikan Akhlak." Jurnal Ilmiah Pedagogy 7, no. 1: 18-30.

Nurhadi, Nurhadi. 2019. "Pendidikan Keluarga Perspektif Hadis Nabi Muhammad Saw." INSANIA: Jurnal Pemikiran Alternatif Kependidikan 24, no. 1: 1-34. https://doi.org/10.24090/insania.v24i1.26 96.

Rochmawati, Nikmah. 2018. "Peran Guru Dan Orang Tua Membentuk Karakter Jujur Pada Anak." Jurnal Al-Fikri: Jurnal Studi Dan Penelitian Pendidikan Islam 1, no. 2: 1-12. https://doi.org/http://dx.doi.org/10.30659 /jspi.v1i2.3203. 
Sahlan, Asmaun. 2012. "Pendidikan Karakter Dalam Perspektif Islam (Kajian Penerapan Pendidikan Karakter Di Lembaga Pendidikan Islam)." Jurnal El-Hikmah Fakultas Tarbiyah UIN Malang 148, no. 50: 148-62.

Setiawan, Eko. 2017. "Konsep Pendidikan Akhlak Anak Perspektif Imam Al Ghazali." Jurnal Kependidikan 5, no. 1: 55-70. https://doi.org/10.24090/jk.v5i1.1252.

Setiyawan, Andi, and Fu`ad Arif Noor. 2021. "Historis Studi Islam Anak Madrasah Ibtidaiyah." Jurnal Ilmiah AL-Jauhari: Jurnal Studi Islam Dan Interdisipliner 6, no. 1: 10523.

https://doi.org/10.30603/jiaj.v6i1.2134.

Siahaan, Amiruddin. 2016. "Profesionalitas Guru Menurut M. Quraish Shihab Dalam Tafsir AlMishbah." MIQOT: Jurnal Ilmu-Ilmu Keislaman 40, no. 2: 308-27. https://doi.org/10.30821/miqot.v40i2.292.

Sitompul, Hafsah. 2018. "Metode Keteladanan Dan Pembiasaan Dalam Penanaman NilaiNilai Dan Pembentukan Sikap Pada Anak." Pembentukan Anak Usia Dini: Keluarga, Sekolah, Dan Komunitas 2, no. 01: 15.

Syahraeni, Andi. 2015. "Tanggung Jawab Keluarga Dalam Pendidikan ANAK." Jurnal Bimbingan Penyuluhan Islam 2, no. 1: 27-45.
Tambak, Syahraini. 2019. "Pendidikan Etika Bergaul Islami Dalam Keluarga 'Nilai Pendidikan Etika Berlaku Adil Orangtua Dengan Anak Dalam Pergaulan Keluarga Perspektif Hadits."' Jurnal Pendidikan Agama Islam Al-Thariqah 4, no. 1: 1-20. https://doi.org/10.25299/althariqah.2019.vol4(1).2910.

Umroh, Ida Latifatul. 2019. "Peran Orang Umroh, I. L. (2019). Peran Orang Tua Dalam Mendidik Anak Sejak Dini Secaraa Islami Di Era Milenial 4.0. Ta'lim: Jurnal Studi Pendidikan Islam, 2(2), 208-225. Http://EJurnal.Unisda.Ac.Id/Index.Php/Talim/Articl e/View/1644Tua Dalam Mendidik Ana." Ta'lim : Jurnal Studi Pendidikan Islam 2, no. 2: 208-25. http://ejurnal.unisda.ac.id/index.php/talim/article/ view/1644.

Yanti, Nova. 2020. "Peranan Remaja Masjid Muslimin Dalam Implementasikan Pendidikan Akhlak Di RW 07 Kelurahan Babussalam Duri." Indonesian Journal of Social Science Education (IJSSE) 2, no. 2: 199-206.

Zamroni, Amin. 2017. "Strategi Pendidikan Akhlak Pada Anak." Sawwa: Jurnal Studi Gender 12, no. 2: 241. https://doi.org/10.21580/sa.v12i2.1544. 